\title{
Tracheal Neoplasm
}

National Cancer Institute

\section{Source}

National Cancer Institute. Tracheal Neoplasm. NCI Thesaurus. Code C3419.

A benign or malignant neoplasm that affects the trachea. Representative examples include tracheal leiomyoma and tracheal carcinoma. 